\section{Structural basis for inhibition of erythrocyte invasion by antibodies to Plasmodium falciparum protein CyRPA}

\author{
Lin Chen ${ }^{1,2+}$, Yibin $\mathrm{Xu}^{1,2 \dagger}$, Wilson Wong ${ }^{1,2}$, Jennifer K Thompson ${ }^{1}$, Julie Healer ${ }^{1}$, \\ Ethan D Goddard-Borger ${ }^{1,2}$, Michael C Lawrence ${ }^{1,2}$, Alan F Cowman ${ }^{1,2 *}$
}

\author{
${ }^{1}$ The Walter and Eliza Hall Institute of Medical Research, Melbourne, Australia; \\ ${ }^{2}$ Department of Medical Biology, University of Melbourne, Melbourne, Australia
}

*For correspondence: cowman@ wehi.edu.au

${ }^{\dagger}$ These authors contributed equally to this work

Competing interests: The authors declare that no competing interests exist.

Funding: See page 12

Received: 12 September 2016 Accepted: 31 January 2017 Published: 14 February 2017

Reviewing editor: Stephen C. Harrison, Harvard Medical School, United States

(c) Copyright Chen et al. This article is distributed under the terms of the Creative Commons Attribution License, which permits unrestricted use and redistribution provided that the original author and source are credited.

\section{Introduction}

The most severe form of malaria in humans is caused by $P$. falciparum with approximately 214 million cases and over 450,000 deaths each year occurring mostly in subtropical and tropical regions of the world (Who, 2015). Infection of humans occurs during blood feeding by a female Anopheles mosquito. The injected parasites migrate to the liver, and after development in hepatocytes liver merozoites are released that quickly invade erythrocytes in the circulating blood. The parasites grow and divide to produce 16 to 32 new daughter merozoites. Following egress from the host cell, these daughter cells invade new erythrocytes perpetuating the asexual blood stage life cycle that is responsible for the symptoms of malaria.

Invasion of human erythrocytes by $P$. falciparum merozoites involves multiple interactions of ligands with host receptors in a complex multistep process that ultimately ends with the internalization of the parasite (reviewed in [Cowman and Crabb, 2006]). The initial interaction of the parasite with the erythrocyte membrane is driven by low affinity interactions involving surface proteins that facilitate apical reorientation. This is followed by high-affinity binding of specific host receptors to the erythrocyte binding-like (EBL) and reticulocyte binding-like homologues (PfRh or PfRBP) ligand families to specific host receptors (reviewed in (Cowman and Crabb, 2006). The PfRh ligands are large proteins, released onto the surface of the merozoite and required for activation of downstream invasion events (Rayner et al., 2000, 2001; Triglia et al., 2001; Tham et al., 2015, 2010). PfRh5 is a disparate member of the PfRh family of ligands because, unlike other members of this protein family, it is small and lacks a transmembrane domain (Hayton et al., 2008; Baum et al., 2009). PfRh5 binds to basigin on the erythrocyte surface (Crosnier et al., 2011). The crystal 
structures of PfRh5 alone (Chen et al., 2014) and in complex with its receptor basigin (Wright et al., 2014) have been determined and the Rh domain shown to exhibit a novel fold.

PfRh5 forms a complex with cysteine-rich protective antigen (CyRPA) and P. falciparum Rh5 interacting protein (PfRipr) (Chen et al., 2011a; Reddy et al., 2015; Volz et al., 2016). The function of PfRh5 is essential and blocking of its interaction with basigin using either soluble basigin or specific antibodies inhibits merozoite invasion (Volz et al., 2016; Weiss et al., 2015). Furthermore, P. falciparum merozoites in which the cyrpa or pfripr genes have been conditionally disrupted also cannot invade human erythrocytes and this process is blocked at the same point as observed when PfRh5 function is inhibited (Volz et al., 2016). The function of the PfRh5/CyRPA/PfRipr complex has been associated with the formation of a discontinuity or pore between the merozoite and the erythrocyte that allows movement of $\mathrm{Ca}^{2+}$ into the host cell. It has also been hypothesized that this protein complex may be directly or indirectly involved in transfer of proteins into the host cell (Volz et al., 2016; Weiss et al., 2015). Regardless of the specific mechanisms at play, the PfRh5/CyRPA/PfRipr complex plays a pivotal role in the sequential molecular events leading to merozoite invasion of erythrocytes.

CyRPA and PfRipr are localized in the micronemes whereas PfRh5 is present at the neck of the rhoptries and these proteins are released onto the surface during merozoite invasion (Volz et al., 2016). Super-resolution microscopy has shown that the tripartite complex forms only at the interface between the invading parasite membrane and the erythrocyte membrane, with pools of PfRh5, CyRPA and PfRipr spread over the surface of the merozoite (Volz et al., 2016). The PfRh5/CyRPA/ PfRipr complex is tightly associated with the membrane, and previous evidence suggested that CyRPA has a glycophosphatidylinositol (GPI) membrane anchor and is responsible for the association of the complex with the merozoite membrane (Reddy et al., 2015). However, it was subsequently shown that CyRPA does not have a GPI anchor, and, as none of these proteins have a transmembrane domain, it remains unclear how they associate with the parasite's plasma membrane (Volz et al., 2016).

Antibodies to PfRh5, PfRipr and CyRPA inhibit merozoite invasion and these proteins are important blood stage malaria vaccine candidates (Chen et al., 2011a; Douglas et al., 2011; Williams et al., 2012; Patel et al., 2013; Reddy et al., 2014). CyRPA-specific monoclonal antibodies inhibit growth of $P$. falciparum in a NOD-scid IL2Ry null mice engrafted with human erythrocytes (Dreyer et al., 2012). Additionally, a PfRh5-based vaccine has been shown to be efficacious in $P$. falciparum challenged aotus monkeys (Douglas et al., 2015).

To understand the molecular basis for blocking of CyRPA function by antibodies, we have co-crystallized this protein with a Fab fragment obtained from an invasion inhibitory monoclonal antibody. We have determined the crystal structure of this complex using diffraction data to $2.44 \AA$ resolution and shown that CyRPA has a six-bladed $\beta$-propeller fold. We have also determined the structure of the uncomplexed CyRPA using data to $3.09 \AA$ resolution. Together, these structures have enabled elucidation of the structural basis for antibody-mediated inhibition of CyRPA-enabled P. falciparum merozoite invasion.

\section{Results}

\section{Recombinant expression of functional CyRPA}

Full-length mature CyRPA (residues 30-362 of the translated protein product) was expressed in insect cells and purified to homogeneity as evidenced by size-exclusion chromatography (SEC) and SDS-PAGE analysis (Figure 1A). Whilst CyRPA has been shown to form a co-complex with PfRh5 and PfRipr (Reddy et al., 2015; Volz et al., 2016), it is not known with which of these two proteins it associates. To determine if the recombinant CyRPA can bind to PfRh5 (Chen et al., 2014), we combined the two proteins and showed by SEC they are capable of forming a stable 1:1 complex. In these experiments, PfRh5 was incubated with excess CyRPA and the stable CyRPA/PfRh5 complex eluted ahead of free CyRPA (Figure 1B). CyRPA/PfRh5 complex formation was also confirmed by incubation of excess CyRPA with FLAG-tagged PfRh5 followed by immunoprecipitation with antiFLAG antibodies. In these experiments, CyRPA co-precipitated with PfRh5 (Figure 1C). Together with the SEC result, this finding suggests an association between CyRPA and PfRh5 within the PfRh5/CyRPA/PfRipr complex during merozoite invasion. These experiments also indicate that our recombinant CyRPA is correctly folded and also functionally competent. 


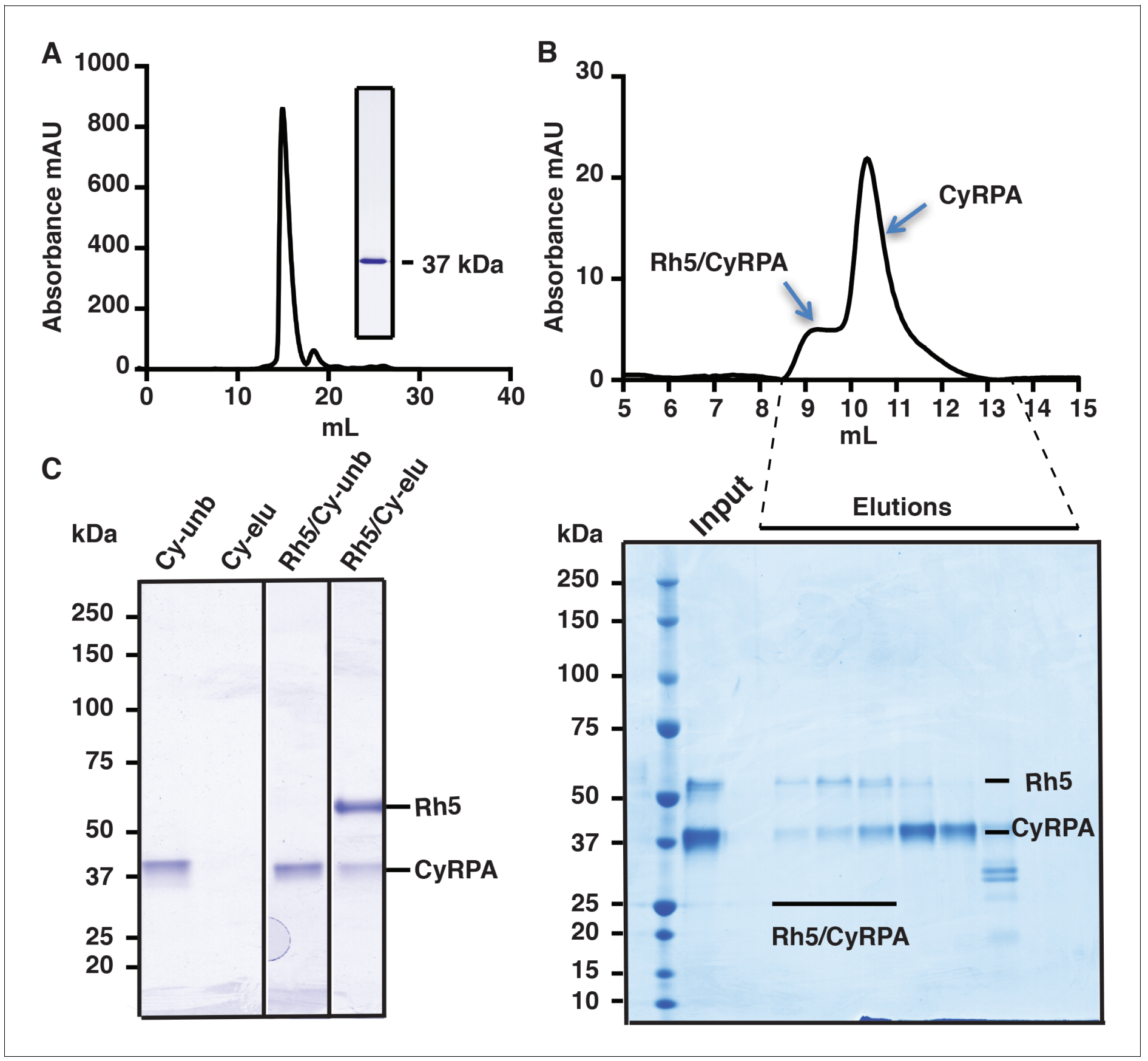

Figure 1. Production of functional recombinant CyRPA. (A) Purified recombinant CyRPA was analysed by size exclusion chromatography and SDSPAGE. (B) Formation of the PfRh5/CyRPA complex was monitored by size exclusion chromatography, CyRPA formed a complex with Rh5 and the complex was eluted in the peak labelled as Rh5/CyRPA. The chromatographic profiles are shown (top panel) and fractions eluted from the column (lower panel) were analysed by SDS-PAGE. (C) Immunoprecipitation of FLAG-PfRh5 after incubation with CyRPA. Cy-unb, CyRPA alone; Cy-eluted, elution from anti-FLAG antibody beads of CyRPA alone; Rh5/Cy-unb, FLAG-PfRh5 and excess CyRPA incubated and unbound protein analysed; Rh5/ Cy-elu, FLAG-PfRh5 and CyRPA eluted from anti-FLAG antibody beads.

\section{CyRPA-specific invasion inhibitory monoclonal antibodies block interaction of CyRPA with PfRh5}

Monoclonal antibodies were raised to recombinant CyRPA and their ability to inhibit $P$. falciparum growth was determined. Three monoclonal antibodies (5B12, 3D1 and 8A7) were identified that inhibited growth to approximately $70 \%$ at $2 \mathrm{mg} / \mathrm{ml}$, whereas others (7A6 and 8B9) showed 
A

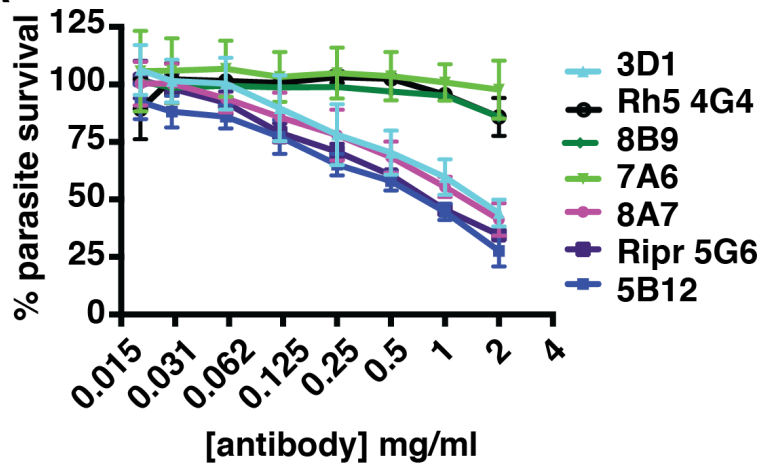

B

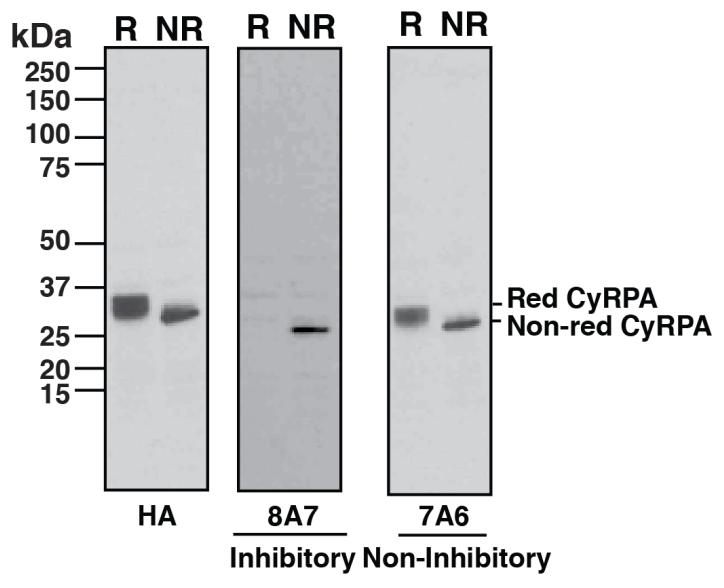

C

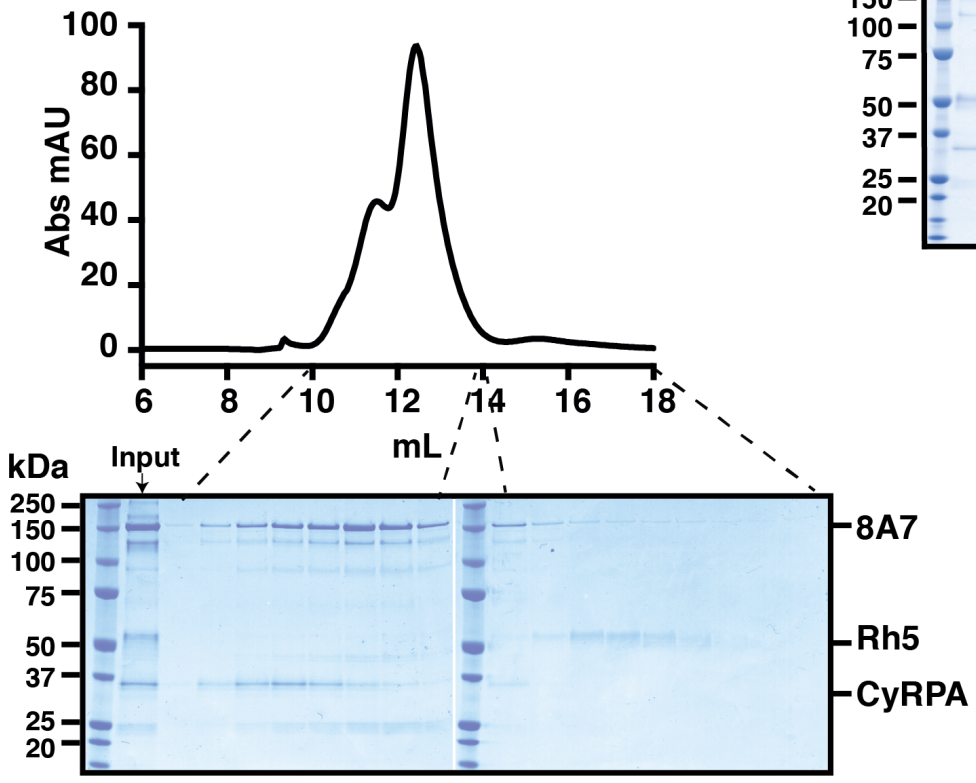

D

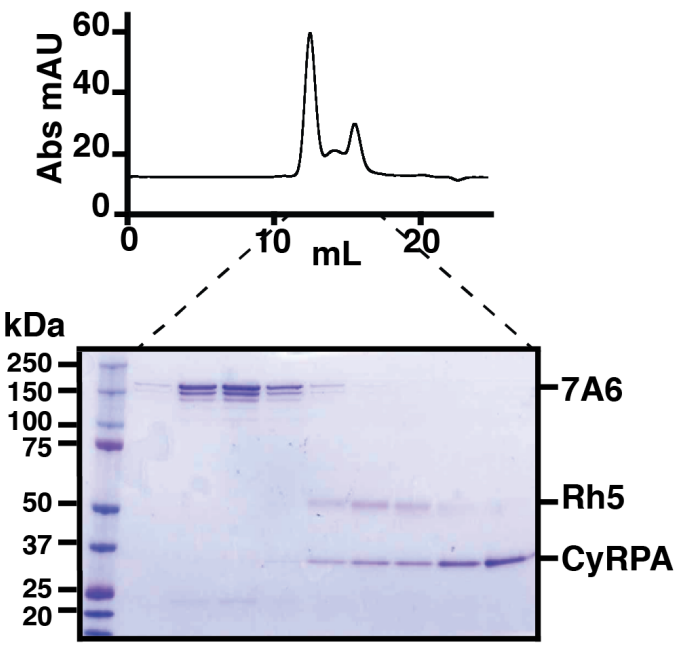

E

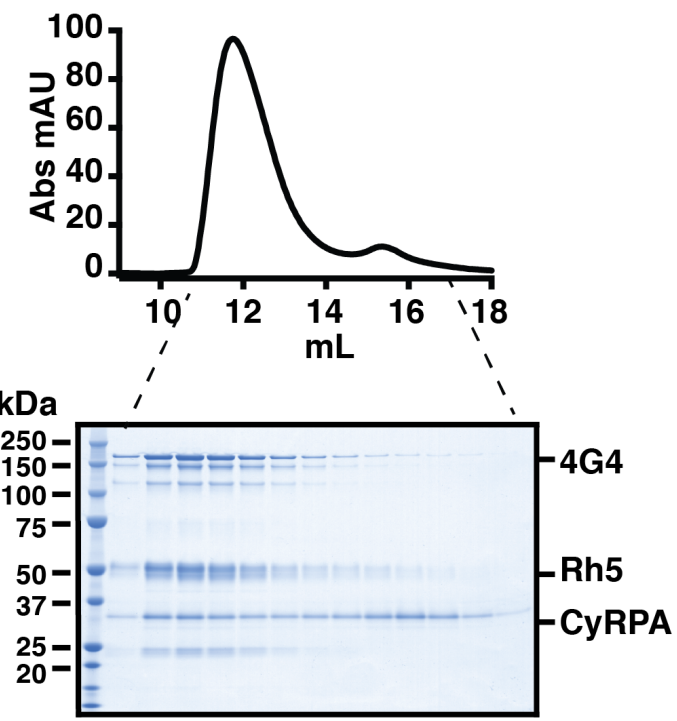

Figure 2. Anti-CyRPA monoclonal antibodies inhibit $P$. falciparum growth and interaction of PfRh5. (A) In vitro growth inhibition (GIA) assays were performed to assess the abilities of the monoclonal antibodies raised against recombinant CyRPA to block $P$. falciparum parasite growth in human erythrocytes. Assays were performed twice in triplicate and error bars denote SD of the mean of 6 values. Anti-Rh5 mAb $4 \mathrm{G} 4$ (not inhibitory) and antiRipr mAb 5 G6 (inhibitory) are included as GIA controls. (B) Immunoblot of inhibitory (8A7) and non-inhibitory (7A6) monoclonal antibodies against

Figure 2 continued on next page 
Figure 2 continued

proteins from CyRPA-HA tagged transgenic $P$. falciparum schizonts in reduced (R) and non-reduced (NR) condition. The $P$. falciparum parasites expressed haemagglutinin-tagged CyRPA protein. (C) Monoclonal antibody 8A7 blocked binding of PfRh5 to CyRPA. PfRh5 and CyRPA were incubated together with 8A7 and the complex formation monitored by size exclusion chromatography and SDS-PAGE analysis under non-reducing conditions. Monoclonal antibody 8A7 bound to CyRPA, preventing the PfRh5/CyRPA complex formation. CyRPA was co-eluted with 8A7 in the earlier fractions and the free Rh5 eluted in the later fractions. (D) Monoclonal antibody 7A6 did not inhibit the formation of the PfRh5/CyRPA complex as monitored by size exclusion chromatography and SDS-PAGE analysis. This antibody did not bind to native CyRPA indicating the linear epitope is not surface exposed. (E) Non-inhibitory anti-PfRh5 monoclonal antibody 4G4 did not significantly inhibit the formation of the PfRh5/CyRPA complex. The PfRh5/CyRPA complex bound to antibody $4 \mathrm{G} 4$ and was eluted together with $4 \mathrm{G} 4$ as a tri-molecule complex in the earlier fractions.

essentially no inhibition (Figure 2A). Immunoblot analysis of CyRPA with the monoclonal antibodies showed those that blocked parasite growth reacted with a conformational epitope as they bound to non-reduced protein but not to reduced protein (Figure 2B). In contrast, the antibodies that did not inhibit parasite growth reacted with both reduced and non-reduced CyRPA, consistent with them binding to a linear epitope. The three inhibitory anti-CyRPA monoclonal antibodies (5B12, 3D1 and 8A7) have a similar potency as the inhibitory anti-Ripr monoclonal antibody $5 \mathrm{G} 6$ in the growth inhibition assays (Figure 2A).

To determine the growth-inhibitory mechanism of the monoclonal antibody 8A7, we performed experiments to examine if the antibody blocked the interaction of CyRPA with PfRh5 (Figure 2C). Both proteins were incubated together in the presence of either inhibitory monoclonal antibody 8A7 or non-inhibitory monoclonal antibody 7A6. The mixtures were analysed by SEC and fractions visualized on SDS-PAGE and stained with Coomassie Blue R250 (Figure 2C and D). In the presence of inhibitory monoclonal antibody 8A7, the formation of the PfRh5/CyRPA complex is disrupted with PfRh5 eluted alone in the later fractions (Figure 2C), and CyRPA eluted as a complex with 8A7 in the earlier fractions. However, in the presence of non-inhibitory monoclonal antibody 7A6, CyRPA remains bound to PfRh5 (Figure 2D). The antibody 7A6 also did not bind to native CyRPA consistent with binding to a linear epitope in immunoblots (Figure 2B) that is not exposed on the surface of the protein. In addition, in the presence of non-inhibitory anti-PfRh5 monoclonal antibody 4G4 (Figure 2A), the PfRh5/CyRPA complex remained largely intact and was eluted as a tri-molecular complex in the earlier fractions, with free CyRPA eluted in the later fractions (Figure 2E). These results suggested that growth-inhibitory mechanism of the monoclonal antibody $8 A 7$ is likely due to the disruption of PfRh5/CyRPA complex formation.

\section{The crystal structures of CyRPA alone and in complex with the Fab fragment of invasion inhibitory monoclonal antibody 8A7}

We crystallized CyRPA in complex with a single 8A7 Fab fragment (see Methods). The structure of the complex was determined using diffraction data to $2.44 \AA$ resolution by molecular replacement using a homologous Fab fragment to obtain initial phases, followed by iterative model building and crystallographic refinement (Figure 3). Crystals were also obtained of uncomplexed CyRPA; this structure was determined by molecular replacement, using the CyRPA component of the Fab-complexed structure as a search model, and subsequently refined using diffraction data to $3.09 \AA$ resolution. Crystallographic data collection and refinement statistics for both structures are shown in Table 1.

The CyRPA structure (Figure 3) displays the canonical six-bladed $\beta$-propeller (6BBP) fold (Figure 3A and B) (Chen et alo, 2011b). Within the $\beta$-propeller structure are four intra-sheet disulfide bonds (Cys19-Cys35, Cys90-Cys92, Cys151-Cys169 and Cys229-Cys239) and one inter-sheet disulfide bond (Cys274-Cys298) (Figure 3A and B). The crystal of uncomplexed CyRPA contains four copies of the protein in the crystallographic asymmetric unit, arranged with approximate 222-point group symmetry (Figure $3 C$ ). Within this tetramer, a pairwise association of CyRPA molecules is mediated by the formation of two eight-strand anti-parallel $\beta$-sheets, one (termed sheet ' $6-6$ ') comprises two copies of the sixth $\beta$-sheet of the CyRPA monomer and the second (termed sheet '5-5') comprises two copies of the (adjacent) fifth $\beta$-sheet of the CyRPA monomer (Figure $3 C$ ). In each case, formation of the eight-stranded sheet is mediated by the respective outermost strands of the two constituent four-stranded sheets. These dimers of CyRPA monomers then associate with each 


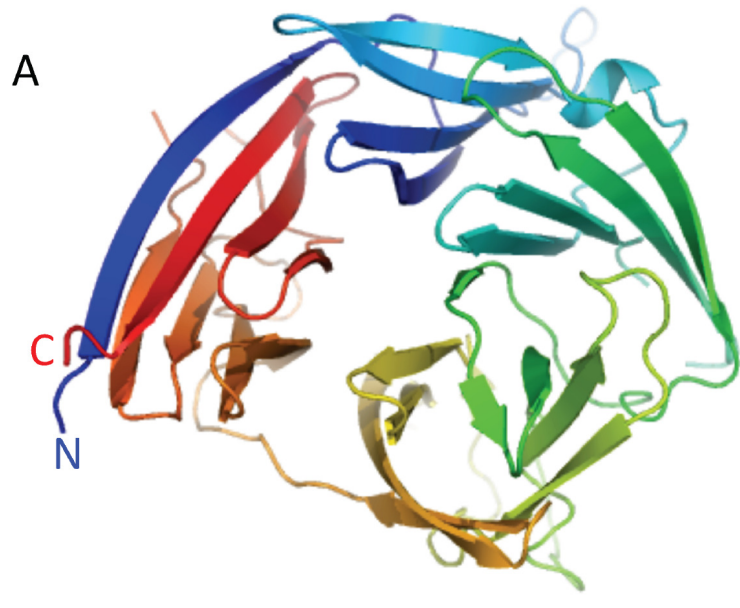

B

201 PYISKNDLSFHFYVGDNINNVKNVNFIECTHEKDLEFVCSNRDFLKDNKV
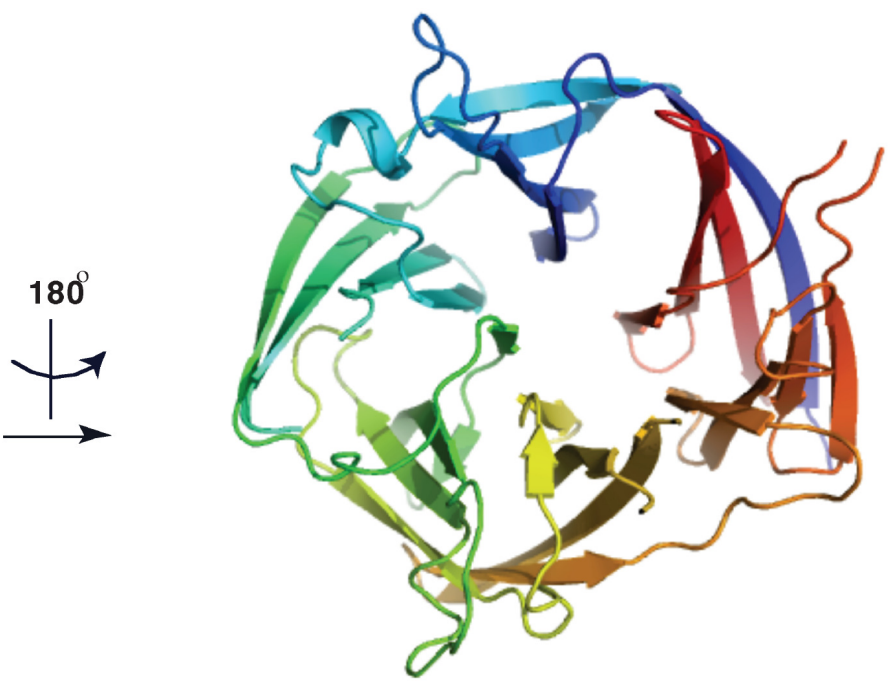

C

50

100

150

200

250

300

350

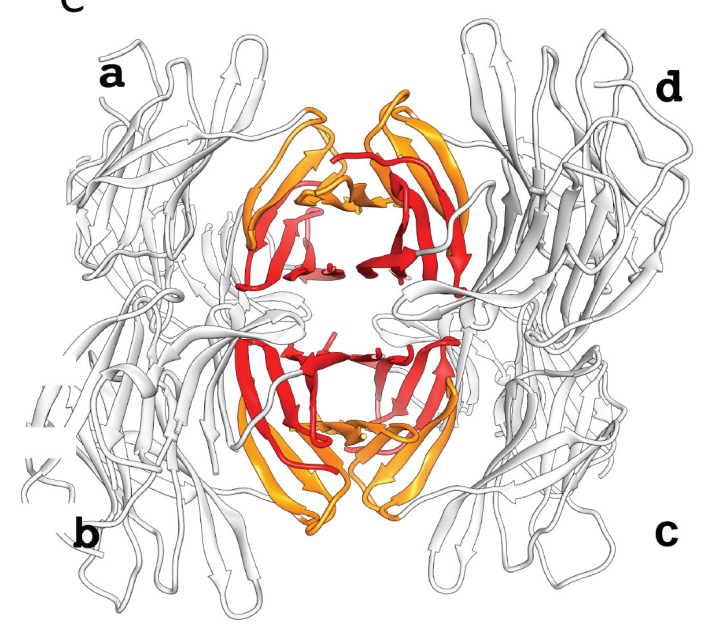

Figure 3. The crystal structure of the uncomplexed CyRPA. (A) Orthogonal view of the ribbon representation of CyRPA, colored in rainbow fashion from the N-terminus (blue) through to the $\mathrm{C}$ - terminus (red). (B) Amino acid sequence and the secondary structure of CyRPA, showing the location of the 24 canonical strands of the six-bladed $\beta$-propeller [labelled ' $\beta m s n^{\prime}$ where the index $n$ denotes the strand and the index $m$ the sheet $(n=1, . ., 4$; $m=1, \ldots, 6)]$. (C) Assembly of the 222 pseudo-symmetric tetramer of CyRPA within the crystallographic asymmetric unit, showing the formation of the extended 5-5 and 6-6 sheets (orange and red, respectively). Each monomer of CyRPA in the asymmetric unit is labelled a, b, c, d. DOI: 10.7554/eLife.21347.004

The following figure supplements are available for figure 3:

Figure supplement 1. Comparison of CyRPA with $C$.

DOI: 10.7554/eLife.21347.005

Figure supplement 2. Recombinant CyRPA does not have sialidase activity.

DOI: 10.7554/eLife.21347.006

other via the formation of a $\beta$-sandwich comprising sheet 6-6 of one CyRPA dimer and sheet 6-6 of the second CyRPA dimer (Figure 3C). The monomer-monomer interfaces, although extensive, are most likely an artefact of crystallization, as we find no evidence for higher-order association upon SEC of CyRPA. However, we cannot rule out such associations occurring within the hetero-complexes formed by CyRPA and its partner proteins on the surface of the merozoite.

The 6BBP fold is found in a number of enzyme families, as well as in some attachment proteins (Chen et alo, 2011b). A DALI search (Holm and Rosenstrom, 2010) reveals that the closest 
Table 1. Data collection and refinement statistics.

\begin{tabular}{|c|c|c|}
\hline & CyRPA & CyRPA/Fab \\
\hline Wavelength $(\AA)$ & 0.954 & 0.954 \\
\hline Resolution range $(\AA ̊)$ & $36.45-3.09(3.20-3.09)^{\star}$ & $38.34-2.44(2.53-2.44)$ \\
\hline Space group & P1 & $P 2{ }_{1} 2_{1} 2_{1}$ \\
\hline $\begin{array}{l}\text { Unit cell } \\
\quad a, b, c(\AA) \\
\quad \alpha, \beta, \gamma\left({ }^{\circ}\right)\end{array}$ & $\begin{array}{l}68.7,83.56,95.32 \\
96.76,104.11,115.20\end{array}$ & $\begin{array}{l}79.95,87.38,145.14 \\
90,90,90\end{array}$ \\
\hline Total no. reflections & $121042(10425)$ & $228716(19565)$ \\
\hline Unique no. reflections & 32250 (2919) & 38347 (3695) \\
\hline Multiplicity & $3.8(3.6)$ & $6.0(5.3)$ \\
\hline Completeness (\%) & $0.98(0.89)$ & $0.99(0.97)$ \\
\hline$<\mid / \sigma(I)>$ & $10.84(1.73)$ & $14.54(2.02)$ \\
\hline Wilson $B$-factor $\left(\AA^{2}\right)$ & 71.27 & 54.65 \\
\hline$R_{\text {merge }}$ & $0.12(0.86)$ & $0.081(1.033)$ \\
\hline$R_{\text {meas }}$ & $0.14(1.01)$ & $0.089(1.137)$ \\
\hline $\mathrm{CC}_{1 / 2}$ & $0.99(0.67)$ & $0.998(0.72)$ \\
\hline$C C^{\star}$ & $1.00(0.90)$ & $1.00(0.915)$ \\
\hline No. reflections used in refinement & $32240(2917)$ & $38345(3695)$ \\
\hline No. reflections used for $R_{\text {free }}$ & $1584(148)$ & $1891(173)$ \\
\hline$R_{\text {work }}$ & $0.1871(0.3620)$ & $0.1887(0.2916)$ \\
\hline$R_{\text {free }}$ & $0.2297(0.4022)$ & $0.2115(0.3000)$ \\
\hline No. non-hydrogen atoms & 10627 & 6045 \\
\hline macromolecules & 10614 & 5990 \\
\hline Ligands & & 12 \\
\hline Protein residues & 1273 & 750 \\
\hline RMS bonds $(\AA)$ & 0.002 & 0.003 \\
\hline RMS angles $\left({ }^{\circ}\right)$ & 0.48 & 0.58 \\
\hline Ramachandran favored (\%) & 95.2 & 97.4 \\
\hline Ramachandran allowed (\%) & 4.8 & 2.6 \\
\hline Ramachandran outliers (\%) & 0 & 0 \\
\hline Rotamer outliers (\%) & 0.58 & 0.29 \\
\hline Clash score & 6.67 & 3.39 \\
\hline Average $B$-factor $\left(\AA^{2}\right)$ & 82.87 & 68.03 \\
\hline Macromolecules & 82.91 & 68.15 \\
\hline Ligand & n.a. & 68.68 \\
\hline Solvent & 45.20 & 51.99 \\
\hline No. TLS groups & 22 & 10 \\
\hline
\end{tabular}

* Statistics for the highest-resolution shell are shown in parentheses.

DOI: 10.7554/eLife.21347.007

structural homologue to CyRPA is the attachment glycoprotein of a henipah virus isolated from Ghanaian bats (PDB entry 4UF7 (Lee et al., 2015)), with the next closest homologues being various sialidases of viral, bacterial and mammalian origin (Varghese et al., 1983; Newstead et al., 2008). CyRPA has up to $16 \%$ sequence identity with all such structural homologues found by the DALI search, suggesting only distant evolutionary relationships, if any, with other thus-far structurally-characterized 6BBPs. Nevertheless, given that sialidases appear consistently as the highest-ranking 
homologues, it is instructive to consider whether CyRPA contains any specific sequence motifs that are characteristic of sialidases and, indeed, whether it has any sialidase activity. We compared the sequence of CyRPA with that of Clostridium perfringens Nanl sialidase to identify potential conserved residues that might be relevant to sialidase enzyme activity. Localization of these residues on an overlay of structures revealed the absence of any potential active site (Figure 3-figure supplement 1) (Newstead et al., 2008). There are two signature motifs for the active site of all sialidases (Varghese et al., 1983; Newstead et al., 2008). The first is a set of three conserved arginine residues that coordinate the binding of the carboxylate moiety of sialic acid (Varghese et alo, 1983; Newstead et al., 2008), these residues are located respectively in the loop between the first and second $\beta$-sheets, in the loop between the third and fourth strand of the fifth $\beta$-sheet and in the loop connecting the second and third strand in the fourth $\beta$-sheet. Inspection reveals only one possible equivalent, an arginine at residue 21 in the loop between the first and second $\beta$-sheets of CyRPA (Figure 3B). The second signature motif is a catalytic tyrosine residue located on the loop between the fifth and sixth $\beta$-sheets (Varghese et al., 1983; Newstead et al., 2008). Again, we find no equivalent in CyRPA to this tyrosine. We further tested whether the recombinant CyRPA had sialidase activity, using the fluorogenic substrate 4-methylumbelliferyl $\mathrm{N}$-acetyl- $\alpha$-D-neuraminic acid as a substrate (see Methods), with bacterial sialidase (neuraminidase) from Arthrobacter ureafaciens as a positive control (Saito et al., 1979). No significant sialidase activity was detected (Figure 3-figure supplement 2). We thus conclude that CyRPA is not a functional sialidase.

\section{The antibody-binding region of CyRPA}

Within the complex, the Fab is oriented (as defined by its long axis) approximately perpendicular to the barrel axis of the 6BBP assembly. The Fab fragment of 8A7 Figure 3B binds to the region of CyRPA comprising residues from the loop between the second and third strands of the first $\beta$-sheet (Gly41, Glu42 and Glu45), residues from the loop between the first and second $\beta$-sheets (Asp63, Lys66, Glu67, Thr68, Asp69, Leu70 and Thr71), residues from the loop between the second and third strands of the second $\beta$-sheet (Lys91 and Lys99), and residues comprising the $\mathrm{N}$-terminal region of the fourth strand of the second $\beta$-sheet (Asn116, Asn117, Ala118 and Glu119) (Figure 3B, Figure 4). Comparison with the uncomplexed CyRPA structures reveals only minor changes in rotameric conformation and relative disposition of CyRPA residues at the interface. The antigen interaction involves residues drawn from all six complementary-determining regions (CDRs) of the Fab and buries a total of $1634 \AA$ of the molecular surface across both molecules (Figure $4 A, B$ and $C$ ). The shape complementarity of the interface $\left(S_{c}=0.71\right)$ is relatively high for antibody-antigen complexes (Lawrence and Colman, 1993), with the surface of CyRPA epitope being predominantly negatively charged (Figure $4 C$ ). The interface itself involves a rich network of approximately nineteen hydrogen bonds (Figure 4B and Figure 4-source data 1).

\section{Discussion}

The PfRh5/CyRPA/PfRipr complex plays an essential role for invasion of $P$. falciparum into human erythrocytes through binding the receptor basigin (Volz et al., 2016). To provide a structural basis for understanding the function of this complex and its components we have determined the structure of CyRPA in its free form. Additionally, we have determined the structure of CyRPA in complex with a Fab fragment derived from a monoclonal antibody that blocks the growth of the $P$. falciparum parasite to understand the mechanism of inhibition. CyRPA displays a canonical six-bladed $\beta$-propeller fold (Chen et alo, 2011b), and the inhibitory monoclonal is shown to block formation of the PfRh5/CyRPA complex.

The closest structural homologue to CyRPA is the attachment glycoprotein of a henipah virus which binds to ephrinB2 and is important for host cell entry (Lee et alo, 2015); however, it also has some similarity to bacterial and viral sialidases all of which have a six-bladed $\beta$-propeller fold (Varghese et alo, 1983; Crennell et al., 1996, 1993, 1994). CyRPA lacks some of the important amino acid motifs required for it to be an active sialidase, and the recombinant form of the protein did not have sialidase activity suggesting it is only distantly related to these enzymes. The PfRh5/ CyRPA/PfRipr complex functions together as a conditional expression of CyRPA or PfRipr and blocking of PfRh5 binding to basigin blocks merozoite invasion at the same step (Volz et al., 2016). Merozoites lacking PfRh5/CyRPA/PfRipr complex function can still interact and deform the erythrocyte 

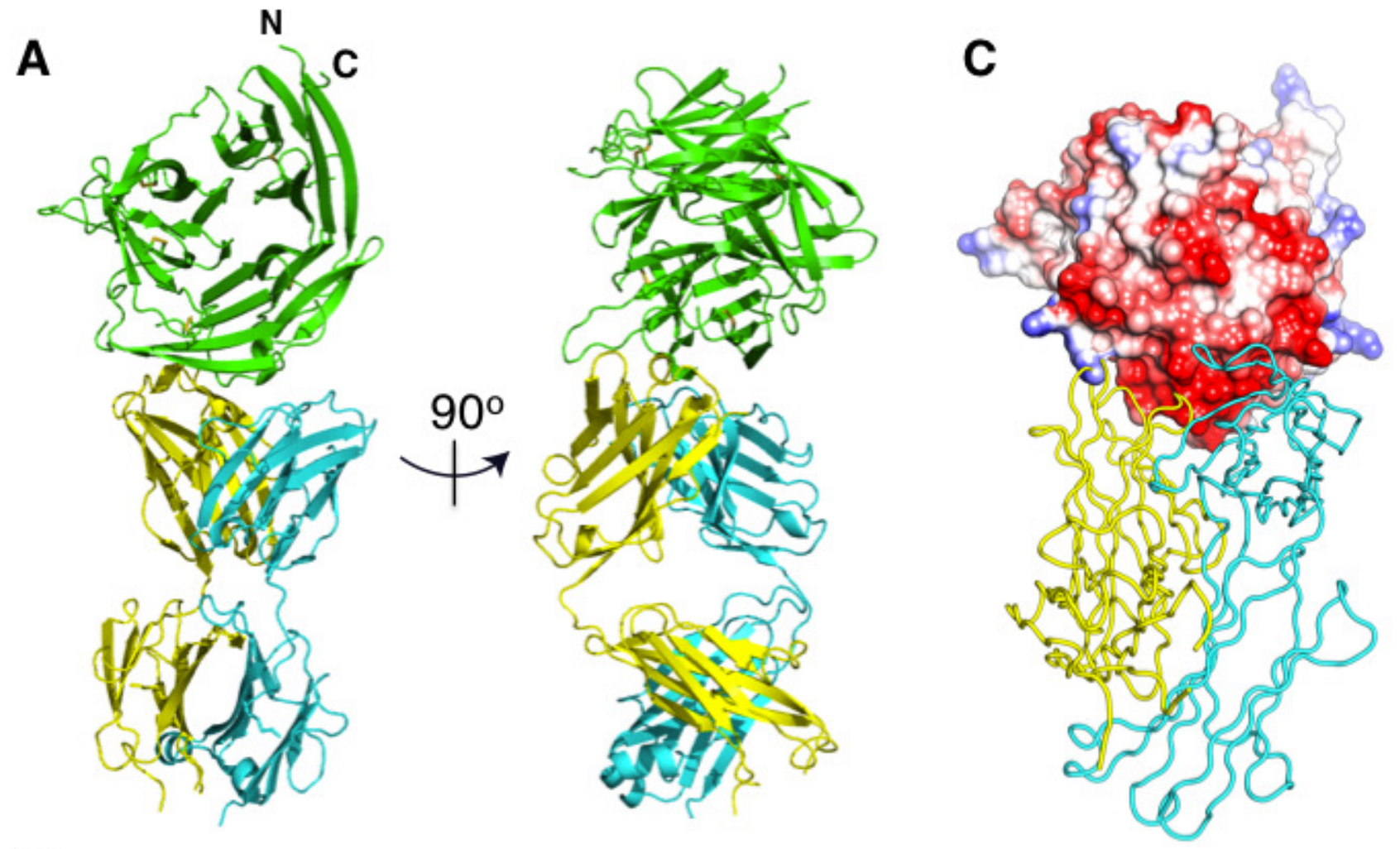

B
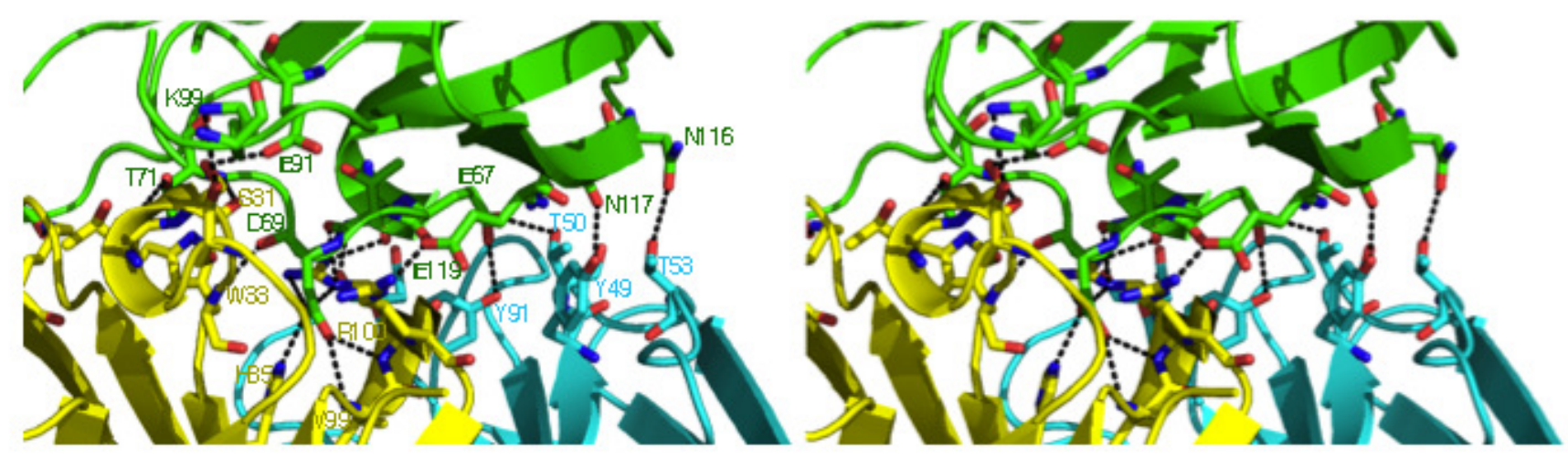

Figure 4. The crystal structure of the Fab 8A7 / CyRPA complex. (A) Orthogonal views of the ribbon representation of the complex (CyRPA: green, Fab 8A7 light chain: cyan; Fab 8A7 heavy chain: yellow. (B) Hydrogen bond network within the interface between Fab 8A7 and CyRPA. (C) Surface of Fab 8A7 epitope of CyRPA colored according to surface potential (red negative, blue positive), with the Fab chain colored as in (A). Surface potential was computed using CHIMERA (Pettersen et al., 2004).

DOI: 10.7554/eLife. 21347.008

The following source data and figure supplement are available for figure 4:

Source data 1. Deduced hydrogen bonds between CyRPA and Fab 8A7.

DOI: 10.7554/eLife.21347.009

Figure supplement 1. Amino acid sequence of anti-CyRPA monoclonal antibody 8A7 Fab fragment for both heavy and light chains. DOI: 10.7554/eLife.21347.010 
membrane but they cannot form the pore or discontinuity between the parasite apical end and the erythrocyte membrane through which $\mathrm{Ca}^{2+}$ passes (Volz et alo, 2016; Weiss et alo, 2015). Therefore, they do not progress to form a tight junction which requires insertion of the RON complex into the host cell (Weiss et al., 2015).

It has been hypothesized that the PfRh5/CyRPA/PfRipr complex is directly involved in forming this pore between the merozoite and erythrocyte membrane (Volz et alo, 2016; Weiss et al., 2015). The PfRh5 structure has a large coiled-coil domain that has some structural similarity with the N-terminal coiled-coil domain of SipB and other similar proteins (Barta et al., 2012). SipB forms part of the Salmonella type III secretion system that transports effector proteins across the host cell membrane. Additionally, there are six-bladed $\beta$-propeller structured proteins, similar to CyRPA, that play a role in the formation of protein translocation channels by bacterial pathogens to inject virulence factors (Meusch et alo, 2014). Whilst these similarities are tantalizing, the link between the formation of a pore between the merozoite surface and the erythrocyte membrane by the PfRh5/CyRPA/PfRipr is circumstantial and requires further evidence (Volz et al., 2016; Weiss et al., 2015).

Our experiments show that CyRPA binds to PfRh5 in the PfRh5/CyRPA/PfRipr tripartite complex and it is likely that it also interacts directly with PfRipr (Volz et alo, 2016). The subcellular localization of CyRPA and PfRipr is in the micronemes whereas PfRh5 is at the neck of the rhoptries and the tripartite complex only forms at the interface between the apical end of the merozoite and the erythrocyte membrane. All three proteins are spread over the free merozoite surface but generally CyRPA and PfRipr co-localise whereas PfRh5 does not. This suggests that the PfRh5/CyRPA/PfRipr complex forms during the invasion process when it is required and that its assembly is finely regulated, most likely requiring the function of other unknown proteins. It is also not understood how the PfRh5/ CyRPA/PfRipr complex or CyRPA associates with the merozoite membrane as none of these proteins have a transmembrane domain or a GPI anchor (Volz et al., 2016).

The anti-CyRPA monoclonal antibody 8A7 directly abrogates the interaction of CyRPA with PfRh5 and as a result directly blocks merozoite invasion of $P$. falciparum into human erythrocytes. This suggests that the PfRh5 binding site for CyRPA overlaps with (or lies close to) the antibody conformational epitope, defined by residues within the loop between the second and third strands of the first $\beta$-sheet, the loop between the first and second $\beta$-sheets, and residues at the $\mathrm{N}$-terminus region of the fourth strand of the second $\beta$-sheet. The absence of large conformational change within CyRPA upon Fab complexation rules out an allosteric mechanism of abrogating a complex formation with PfRh5. Therefore, blocking of the CyRPA and PfRh5 interaction by antibodies is consistent with a functional PfRh5/CyRPA/PfRipr complex assembling at the interface between the invading merozoite and erythrocyte membrane (Volz et al., 2016).

CyRPA is a highly conserved protein in P. falciparum and the antibody binding epitope as well as the remainder of the protein is not under selective pressure. As a result, it is a promising vaccine candidate as antibodies inhibit merozoite invasion in vitro as well as in mice engrafted with human erythrocytes (Reddy et al., 2014; Dreyer et al., 2012). Our results elucidate the structural basis for the binding and inhibition of antibodies to CyRPA that block merozoite invasion. This information will facilitate the development of this candidate in potential vaccines most likely in a combination vaccine with PfRh5 and PfRipr or in the complex form of PfRh5/CyRPA/PfRipr against malaria.

\section{Materials and methods}

\section{Protein expression and purification}

Plasmodium falciparum (3D7) full-length mature CyRPA with the last residues of the three potential glycosylation site motifs mutated to alanine ( ${ }^{116} \mathrm{NNS}$ to NNA, ${ }^{293} \mathrm{NTT}$ to NTA and ${ }^{299}$ NRT to NRA) was cloned in to the vector pgpHFT (Xu et alo, 2010) and expressed in insect cells as described (Chen et alo, 2011a), but employing in this instance Sf21 cells rather than Hi5 cells. The supernatant containing the secreted recombinant protein was harvested, centrifuged and passed over an antiFLAG M2 agarose (Sigma) column. After extensive washing, bound proteins were eluted from the column with FLAG peptide at a concentration of $100 \mu \mathrm{g} / \mathrm{ml}$, concentrated and then further purified by size-exclusion chromatography (SEC) with a Superdex 200 column (GL 10/300, GE Healthcare) in $25 \mathrm{mM}$ HEPES, $150 \mathrm{mM} \mathrm{NaCl}, \mathrm{pH}$ 7.2. For crystallization of CyRPA, the tandem hexa-His and FLAG tags were removed by digestion with a TEV protease and purified protein was recovered by Ni-resin 
and/or SEC. The Fab fragment of anti-CyRPA monoclonal 8A7 (see below for details of monoclonal antibody production and growth inhibition assays) was prepared by digesting the monoclonal antibody parent with papain and then purifying by SEC using a Superdex 200 column (GL 10/300; GE Healthcare). The CyRPA/Fab complex was prepared by combining an excess of CyRPA with the Fab fragment followed by purification of the complex by SEC.

To obtain the amino acid sequence of the VH and VL segments of 8A7 total RNA was isolated from the hybridoma cells following the technical manual of TRlzol Reagent. Total RNA was then reverse transcribed into cDNA using lgG1 kappa-specific anti-sense primers or universal primers following the technical manual of PrimeScriptTM 1st Strand cDNA Synthesis Kit. The antibody fragments of $\mathrm{VH}$ and $\mathrm{VL}$ were amplified according to the standard operating procedure of rapid amplification of cDNA ends (RACE) of GenScript (New Jersey). Amplified antibody fragments were cloned separately into a standard cloning vector separately. Colony PCR was performed to screen for clones with inserts of correct sizes. No fewer than five colonies with inserts of correct sizes were sequenced for each fragment. The sequences of different clones were aligned and the consensus sequence of these clones was obtained.

\section{Production of monoclonal antibodies and growth inhibition assays}

All procedures with mice were approved by the Walter and Eliza Hall Medical Research Institute Animal Ethics Committee. BALB/c mice were immunized with $20 \mu \mathrm{g}$ of recombinant CyRPA in Freund's complete adjuvant (1st injection; Sigma Aldrich) followed by two subsequent injections of $20 \mu \mathrm{g}$ CyRPA in Freund's incomplete adjuvant (two subsequent injections; Sigma Aldrich, St. Louis, MO) then $40 \mu \mathrm{g}$ CyRPA in saline and $50 \mu \mathrm{g}$ CyRPA in saline. Mice were euthanized and spleens harvested using aseptic technique. Spleen cells were fused with myeloma cells. Anti-CyRPA antibody-producing hybridoma cell lines were identified 14 days after fusion, using ELISA with recombinant CyRPA. Positive hybridomas were sub-cloned to obtain monoclonal cell lines. Positive antibodies were subsequently screened by immuno-blot with mature schizonts. Monoclonal antibodies 7A6, 8B9, 3D1, $8 \mathrm{~A} 7$ and $5 \mathrm{~B} 12$ were selected for further study and tested to determine if they inhibit $P$. falciparum growth in vitro. 8A7 was used for co-crystallography studies and is isotype IgG1 kappa. Non-inhibitory anti-PfRh5 monoclonal antibody 4G4 and inhibitory anti-PfRipr monoclonal antibody 5G6 were included as controls.

Two cycle growth inhibition assays were performed, using 3D7 strain of $P$. falciparum, as described to determine if the monoclonal antibodies inhibited parasite growth (Healer et al., 2013). Serial dilutions of $\mathrm{lgG}$ in PBS, starting at $2 \mathrm{mg} / \mathrm{ml}$ were added to $P$. falciparum-infected erythrocytes (3D7) at a parasitaemia of $0.1 \%$. Parasitaemia was counted after $96 \mathrm{hr}$ by flow cytometry and specific growth inhibition calculated relative to parasites grown in non-immune lgG. $P$. falciparum strain 3D7 has been confirmed by whole genome sequencing and was originally obtained from Prof. David Walliker, Edinburgh University.

\section{Immuno-blot screen of anti-CyRPA monoclonal antibodies}

Synchronized schizont stage 3D7 parasites that expressed HA-tagged CyRPA (Volz et al., 2016) were harvested and erythrocytes lysed using $0.15 \%$ saponin. Proteins were solubilized from the saponin pellet with reducing and non-reducing SDS-PAGE sample buffer and separated on 4-12\% bis-Tris precast NuPAGE gel (Life Technologies, Carlsbad, $\mathrm{Ca}$, USA) then transferred to a nitrocellulose membrane. The membranes were probed with the anti-CyRPA monoclonal antibodies (1/1000) and anti-HA mouse monoclonal (1/1000) as a positive control and proteins detected by enhanced chemiluminescence (ECL, GE Healthcare).

\section{SEC and co-immunoprecipitation}

SEC was performed on an analytical Superdex 200 column or Superose-6 column (24 ml, GE Healthcare) and proteins were eluted with $25 \mathrm{mM}$ HEPES, $150 \mathrm{mM} \mathrm{NaCl}, \mathrm{pH} 7.2$ or $25 \mathrm{mM}$ Tris, $150 \mathrm{mM}$ $\mathrm{NaCl}, \mathrm{pH}$ 8.5. Co-immunoprecipitation of CyRPA with FLAG-tagged PfRh5 was performed using anti-FLAG M2 agarose (Sigma). Briefly, $5 \mu \mathrm{g}$ FLAG-tagged PfRh5 and $5 \mu \mathrm{g}$ CyRPA were incubated with $20 \mu \mathrm{l}$ anti-FLAG M2 agarose beads for $1 \mathrm{hr}$ on ice. After extensive washing with $25 \mathrm{mM}$ Tris, $\mathrm{pH}$ 8.5 buffer containing $150 \mathrm{mM} \mathrm{NaCl}$, the bound proteins were eluted with the FLAG peptide at a 
concentration of $100 \mu \mathrm{g} / \mathrm{ml}$ in the same Tris buffer, analysed by SDS-PAGE and stained with Coomassie Blue R250.

\section{Crystallization and structure determination}

Crystallization trials for both the Fab-bound and the uncomplexed CyRPA protein were initially performed in sitting-drop, 96-well format at $18^{\circ} \mathrm{C}$ performed at the CSIRO Collaborative Crystallization Centre (Parkville, Australia), followed by in-house refinement. Diffracting crystals of CyRPA were finally obtained from hanging drops containing 9\% PEG1000, 9\% PEG8000, $0.25 \mathrm{M}$ potassium iodide and $50 \mathrm{mM}$ potassium thiocyanate. Diffracting crystals of CyRPA/Fab complex were finally obtained from hanging drops containing $11 \%$ PEG5000 monomethyl ether and $0.2 \mathrm{M}$ sodium acetate, pH 5.5. For data collection, crystals were transferred to cryo-protection solutions (12\% PEG1000, $12 \%$ PEG8000, $0.25 \mathrm{M}$ potassium iodide, $50 \mathrm{mM}$ potassium thiocyanate and $25 \%$ ethylene glycol for CyRPA crystals; $15 \%$ PEG5000 monomethyl ether and $0.2 \mathrm{M}$ sodium acetate, $\mathrm{pH} 5.5 \%$ and $25 \%$ ethylene glycol for CyRPA/Fab complex crystals) and cryo-cooled by plunging into liquid nitrogen. X-ray diffraction data were collected on beamline MX2 at the Australian Synchrotron at a temperature of $100 \mathrm{~K}$ (McPhillips et al., 2002).

Diffraction data were processed and scaled with XDS (Kabsch, 2010). Resolution limits were set to $3.09 \AA$ for the native CyRPA crystal data and to $2.44 \AA$ for the CyRPA/Fab complex crystal data. For the structure solution of CyRPA/Fab complex, initial phases were obtained by molecular replacement using PHASER (McCoy et al., 2007) with the structure of a murine Fab fragment (PDB code: 5L9D; unpublished) as a search model within PHASER (Kabsch, 2010). Model building and refinement then continued within PHENIX (Adams et alo, 2010), with automated building and morphing routines leading to a model comprising the majority of the CyRPA/Fab sequence. Further rounds of refinement and manual rebuilding were undertaken using PHENIX (Adams et alo, 2010) and COOT (Emsley et alo, 2010). The structure of the native CyRPA was solved by molecular replacement with coordinates of CyRPA-derived from the refined CyRPA/Fab structure-used as a search model. Data processing and refinement statistics for both structures are provided in Table 1.

\section{Sialidase assay}

Sialidase (i.e., neuraminidase) activity was assayed using the fluorogenic substrate 4-methylumbelliferyl $\mathrm{N}$-acetyl- $\alpha$-D-neuraminic acid sodium salt (4 mU-NeuNAc). Reaction volumes (100 $\mu$ l) containing $4 \mathrm{mU}-\mathrm{NeuNAc}(100 \mu \mathrm{M})$ at $\mathrm{pH} 5.0(50 \mathrm{mM}$ citrate, $150 \mathrm{mM} \mathrm{NaCl}), \mathrm{pH} 6.5(50 \mathrm{mM}$ MES, $150 \mathrm{mM}$ $\mathrm{NaCl})$ and pH $8.0(50 \mathrm{mM}$ Tris- $\mathrm{HCl}, 150 \mathrm{mM} \mathrm{NaCl})$ were incubated with BSA $(5 \mu \mathrm{g} / \mathrm{ml})$, CyRPA $(5.0$ $\mu \mathrm{g} / \mathrm{ml}$ ) or Arthrobacter ureafaciens sialidase (neuraminidase) (Sigma-Aldrich N3786, $0.1 \mu \mathrm{g} / \mathrm{ml}$ ) for 4 $\mathrm{hr}$ at $37^{\circ} \mathrm{C}$. Each reaction was quenched with glycine buffer $(900 \mu \mathrm{l}, 1 \mathrm{M}, \mathrm{pH} 10)$ and fluorescence measured ( $\lambda_{\mathrm{ex}}=365 \mathrm{~nm}, \lambda_{\mathrm{em}}=445 \mathrm{~nm}$ ) on a Cary Eclipse fluorimeter (Agilent Technologies). These values, obtained in triplicate, were normalized with respect to the fluorescence measured for $10 \mu \mathrm{M}$ 4-methylumbelliferone in glycine buffer $(0.9 \mathrm{M}, \mathrm{pH} 10)$ to determine the completeness of each reaction.

\section{Acknowledgements}

We thank the Victorian Red Cross Blood Bank for the supply of blood and Kaye Wycherley and Paul Masendycz of the WEHI Monoclonal Facility for production of monoclonal antibodies. Part of the research was undertaken on the MX2 beamline at the Australian Synchrotron, Victoria, Australia.

\section{Additional information}

Funding

Funder

Victorian State Government
Grant reference number

Independent Research Institute Infrastructure

Support Scheme
Author

Lin Chen

Yibin Xu

Wilson Wong

Jennifer K Thompson

Ethan D Goddard-Borger

Michael C Lawrence 
Alan F Cowman

\begin{tabular}{|c|c|c|}
\hline $\begin{array}{l}\text { National Health and Medical } \\
\text { Research Council }\end{array}$ & $\begin{array}{l}\text { Independent Research } \\
\text { Institute Infrastructure } \\
\text { Support Scheme }\end{array}$ & $\begin{array}{l}\text { Lin Chen } \\
\text { Yibin Xu } \\
\text { Wilson Wong } \\
\text { Jennifer K Thompson } \\
\text { Ethan D Goddard-Borger }\end{array}$ \\
\hline $\begin{array}{l}\text { Howard Hughes Medical Insti- } \\
\text { tute }\end{array}$ & 55007645 & Alan F Cowman \\
\hline $\begin{array}{l}\text { National Health and Medical } \\
\text { Research Council }\end{array}$ & 637406 & Alan F Cowman \\
\hline Path/Malaria Vaccine Initiative & 07608-COL & Alan F Cowman \\
\hline $\begin{array}{l}\text { United States Agency for In- } \\
\text { ternational Development }\end{array}$ & 07608-COL & Alan F Cowman \\
\hline
\end{tabular}

The funders had no role in study design, data collection and interpretation, or the decision to submit the work for publication.

Author contributions

LC, Conception and design, Acquisition of data, Analysis and interpretation of data, Drafting and revising the article; YX, WW, JKT, JH, EDG-B, Acquisition of data, Analysis and interpretation of data; MCL, Analysis and interpretation of data, Drafting and revision of manuscript; AFC, Conception and design, Analysis and interpretation of data, Drafting and revision of the manuscript

Author ORCIDs

Alan F Cowman, (DiD http://orcid.org/0000-0001-5145-9004

\section{Additional files}

Major datasets

The following datasets were generated:

\begin{tabular}{|c|c|c|c|c|}
\hline Author(s) & Year & Dataset title & Dataset URL & $\begin{array}{l}\text { Database, license, } \\
\text { and accessibility } \\
\text { information }\end{array}$ \\
\hline $\begin{array}{l}\text { Lin Chen, Yibin Xu, } \\
\text { Wilson Wong, Jen- } \\
\text { nifer K Thompson, } \\
\text { Julie Healer, Ethan } \\
\text { D Goddard-Borger, } \\
\text { Michael C Lawr- } \\
\text { ence, Alan F Cow- } \\
\text { man }\end{array}$ & 2017 & $\begin{array}{l}\text { Structural basis for inhibition of } \\
\text { erythrocyte invasion by antibodies } \\
\text { to Plasmodium falciparum protein } \\
\text { CyRPA }\end{array}$ & $\begin{array}{l}\text { http://www.rcsb.org/ } \\
\text { pdb/explore/explore.do? } \\
\text { structureld=5TIH }\end{array}$ & $\begin{array}{l}\text { Publicly available at } \\
\text { the RCSB Protein } \\
\text { Data Bank (Accession } \\
\text { no: } 5 \text { TIH) }\end{array}$ \\
\hline $\begin{array}{l}\text { Lin Chen, Yibin Xu, } \\
\text { Wilson Wong, Jen- } \\
\text { nifer K Thompson, } \\
\text { Julie Healer, Ethan } \\
\text { D Goddard-Borger, } \\
\text { Michael C Lawr- } \\
\text { ence, Alan F Cow- } \\
\text { man }\end{array}$ & 2017 & $\begin{array}{l}\text { Structural basis for inhibition of } \\
\text { erythrocyte invasion by antibodies } \\
\text { to Plasmodium falciparum protein } \\
\text { CyRPA }\end{array}$ & $\begin{array}{l}\text { http://www.rcsb.org/ } \\
\text { pdb/explore/explore.do? } \\
\text { structureld=5TIK }\end{array}$ & $\begin{array}{l}\text { Publicly available at } \\
\text { the RCSB Protein } \\
\text { Data Bank (Accession } \\
\text { no: } 5 \text { TIK) }\end{array}$ \\
\hline
\end{tabular}

\section{References}

Adams PD, Afonine PV, Bunkóczi G, Chen VB, Davis IW, Echols N, Headd JJ, Hung LW, Kapral GJ, GrosseKunstleve RW, McCoy AJ, Moriarty NW, Oeffner R, Read RJ, Richardson DC, Richardson JS, Terwilliger TC, Zwart PH. 2010. PHENIX: a comprehensive Python-based system for macromolecular structure solution. Acta Crystallographica Section D Biological Crystallography 66:213-221. doi: 10.1107/S0907444909052925, PMID: 20124702

Barta ML, Dickenson NE, Patil M, Keightley A, Wyckoff GJ, Picking WD, Picking WL, Geisbrecht BV. 2012. The structures of coiled-coil domains from type III secretion system translocators reveal homology to pore-forming toxins. Journal of Molecular Biology 417:395-405. doi: 10.1016/j.jmb.2012.01.026, PMID: 22321794 
Baum J, Chen L, Healer J, Lopaticki S, Boyle M, Triglia T, Ehlgen F, Ralph SA, Beeson JG, Cowman AF. 2009. Reticulocyte-binding protein homologue 5 - an essential adhesin involved in invasion of human erythrocytes by plasmodium falciparum. International Journal for Parasitology 39:371-380. doi: 10.1016/j.ijpara.2008.10.006, PMID: 19000690

Chen L, Lopaticki S, Riglar DT, Dekiwadia C, Uboldi AD, Tham WH, O'Neill MT, Richard D, Baum J, Ralph SA, Cowman AF. 2011a. An EGF-like protein forms a complex with PfRh5 and is required for invasion of human erythrocytes by plasmodium falciparum. PLoS Pathogens 7:e1002199. doi: 10.1371/journal.ppat.1002199, PMID: 21909261

Chen CK, Chan NL, Wang AH. 2011b. The many blades of the $\beta$-propeller proteins: conserved but versatile. Trends in Biochemical Sciences 36:553-561. doi: 10.1016/j.tibs.2011.07.004, PMID: 21924917

Chen L, Xu Y, Healer J, Thompson JK, Smith BJ, Lawrence MC, Cowman AF. 2014. Crystal structure of PfRh5, an essential P. falciparum ligand for invasion of human erythrocytes. eLife 3:e04187. doi: 10.7554/eLife.04187

Collaborative Computational Project N. 1994. The CCP4 suite: programs for protein crystallography. Acta Crystallographica. Section D, Biological Crystallography 50:760-763. doi: 10.1107/S0907444994003112, PMID: 15299374

Cowman AF, Crabb BS. 2006. Invasion of red blood cells by malaria parasites. Cell 124:755-766. doi: 10.1016/j. cell.2006.02.006, PMID: 16497586

Crennell S, Garman E, Laver G, Vimr E, Taylor G. 1994. Crystal structure of Vibrio cholerae neuraminidase reveals dual lectin-like domains in addition to the catalytic domain. Structure 2:535-544. doi: 10.1016/S0969-2126(00) 00053-8, PMID: 7922030

Crennell SJ, Garman EF, Laver WG, Vimr ER, Taylor GL. 1993. Crystal structure of a bacterial sialidase (from Salmonella typhimurium LT2) shows the same fold as an influenza virus neuraminidase. PNAS 90:9852-9856. doi: 10.1073/pnas.90.21.9852, PMID: 8234325

Crennell SJ, Garman EF, Philippon C, Vasella A, Laver WG, Vimr ER, Taylor GL. 1996. The structures of Salmonella typhimurium LT2 neuraminidase and its complexes with three inhibitors at high resolution. Journal of Molecular Biology 259:264-280. doi: 10.1006/jmbi.1996.0318, PMID: 8656428

Crosnier C, Bustamante LY, Bartholdson SJ, Bei AK, Theron M, Uchikawa M, Mboup S, Ndir O, Kwiatkowski DP, Duraisingh MT, Rayner JC, Wright GJ. 2011. Basigin is a receptor essential for erythrocyte invasion by plasmodium falciparum. Nature 480(7378):534-537. doi: 10.1038/nature10606

Douglas AD, Baldeviano GC, Lucas CM, Lugo-Roman LA, Crosnier C, Bartholdson SJ, Diouf A, Miura K, Lambert LE, Ventocilla JA, Leiva KP, Milne KH, Illingworth JJ, Spencer AJ, Hjerrild KA, Alanine DG, Turner AV, Moorhead JT, Edgel KA, Wu Y, et al. 2015. A PfRH5-based vaccine is efficacious against heterologous strain blood-stage plasmodium falciparum infection in aotus monkeys. Cell Host \& Microbe 17:130-139. doi: 10. 1016/j.chom.2014.11.017, PMID: 25590760

Douglas AD, Williams AR, Illingworth JJ, Kamuyu G, Biswas S, Goodman AL, Wyllie DH, Crosnier C, Miura K, Wright GJ, Long CA, Osier FH, Marsh K, Turner AV, Hill AV, Draper SJ. 2011. The blood-stage malaria antigen $\mathrm{PfRH} 5$ is susceptible to vaccine-inducible cross-strain neutralizing antibody. Nature Communications 2:601. doi: 10.1038/ncomms1615, PMID: 22186897

Dreyer AM, Matile H, Papastogiannidis P, Kamber J, Favuzza P, Voss TS, Wittlin S, Pluschke G. 2012. Passive immunoprotection of plasmodium falciparum-infected mice designates the CyRPA as candidate malaria vaccine antigen. The Journal of Immunology 188:6225-6237. doi: 10.4049/jimmunol.1103177, PMID: 22593616

Emsley P, Lohkamp B, Scott WG, Cowtan K. 2010. Features and development of coot. Acta Crystallographica Section D Biological Crystallography 66:486-501. doi: 10.1107/S0907444910007493, PMID: 20383002

Hayton K, Gaur D, Liu A, Takahashi J, Henschen B, Singh S, Lambert L, Furuya T, Bouttenot R, Doll M, Nawaz F, Mu J, Jiang L, Miller LH, Wellems TE. 2008. Erythrocyte binding protein PfRH5 polymorphisms determine species-specific pathways of plasmodium falciparum invasion. Cell Host \& Microbe 4:40-51. doi: 10.1016/j. chom.2008.06.001, PMID: 18621009

Healer J, Thompson JK, Riglar DT, Wilson DW, Chiu YH, Miura K, Chen L, Hodder AN, Long CA, Hansen DS, Baum J, Cowman AF. 2013. Vaccination with conserved regions of erythrocyte-binding antigens induces neutralizing antibodies against multiple strains of plasmodium falciparum. PLoS One 8:e72504. doi: 10.1371/ journal.pone.0072504, PMID: 24039774

Holm L, Rosenström P. 2010. Dali server: conservation mapping in 3D. Nucleic Acids Research 38:W545-W549. doi: 10.1093/nar/gkq366, PMID: 20457744

Kabsch W. 2010. XDS. Acta Crystallographica. Section D, Biological Crystallography 66:125-132. doi: 10.1107/ S0907444909047337, PMID: 20124692

Lawrence MC, Colman PM. 1993. Shape complementarity at protein/protein interfaces. Journal of Molecular Biology 234:946-950. doi: 10.1006/jmbi.1993.1648, PMID: 8263940

Lee B, Pernet O, Ahmed AA, Zeltina A, Beaty SM, Bowden TA. 2015. Molecular recognition of human ephrinB2 cell surface receptor by an emergent african Henipavirus. PNAS 112:E2156-E2165. doi: 10.1073/pnas. 1501690112, PMID: 25825759

McCoy AJ, Grosse-Kunstleve RW, Adams PD, Winn MD, Storoni LC, Read RJ. 2007. Phaser crystallographic software. J Appl Cryst 40:658-674. doi: 10.1107/S0021889807021206

McPhillips TM, McPhillips SE, Chiu HJ, Cohen AE, Deacon AM, Ellis PJ, Garman E, Gonzalez A, Sauter NK, Phizackerley RP, Soltis SM, Kuhn P. 2002. Blu-lce and the distributed control system: software for data acquisition and instrument control at macromolecular crystallography beamlines. Journal of Synchrotron Radiation 9:401-406. doi: 10.1107/S0909049502015170, PMID: 12409628 
Meusch D, Gatsogiannis C, Efremov RG, Lang AE, Hofnagel O, Vetter IR, Aktories K, Raunser S. 2014. Mechanism of tc toxin action revealed in molecular detail. Nature 508:61-65. doi: 10.1038/nature13015, PMID: 24572368

Newstead SL, Potter JA, Wilson JC, Xu G, Chien CH, Watts AG, Withers SG, Taylor GL. 2008. The structure of Clostridium perfringens Nanl sialidase and its catalytic intermediates. Journal of Biological Chemistry 283: 9080-9088. doi: 10.1074/jbc.M710247200, PMID: 18218621

Patel SD, Ahouidi AD, Bei AK, Dieye TN, Mboup S, Harrison SC, Duraisingh MT. 2013. Plasmodium falciparum merozoite surface antigen, PfRH5, elicits detectable levels of invasion-inhibiting antibodies in humans. Journal of Infectious Diseases 208:1679-1687. doi: 10.1093/infdis/jit385, PMID: 23904294

Pettersen EF, Goddard TD, Huang CC, Couch GS, Greenblatt DM, Meng EC, Ferrin TE. 2004. UCSF chimera-a visualization system for exploratory research and analysis. Journal of Computational Chemistry 25:1605-1612. doi: 10.1002/jcc.20084, PMID: 15264254

Rayner JC, Galinski MR, Ingravallo P, Barnwell JW. 2000. Two plasmodium falciparum genes express merozoite proteins that are related to Plasmodium vivax and Plasmodium yoelii adhesive proteins involved in host cell selection and invasion. PNAS 97:9648-9653. doi: 10.1073/pnas.160469097, PMID: 10920203

Rayner JC, Vargas-Serrato E, Huber CS, Galinski MR, Barnwell JW. 2001. A plasmodium falciparum homologue of Plasmodium vivax reticulocyte binding protein (PvRBP1) defines a trypsin-resistant erythrocyte invasion pathway. The Journal of Experimental Medicine 194:1571-1582. doi: 10.1084/jem.194.11.1571, PMID: 11733572

Reddy KS, Amlabu E, Pandey AK, Mitra P, Chauhan VS, Gaur D. 2015. Multiprotein complex between the GPIanchored CyRPA with PfRH5 and PfRipr is crucial for plasmodium falciparum erythrocyte invasion. PNAS 112: 1179-1184. doi: 10.1073/pnas.1415466112, PMID: 25583518

Reddy KS, Pandey AK, Singh H, Sahar T, Emmanuel A, Chitnis CE, Chauhan VS, Gaur D. 2014. Bacterially expressed full-length recombinant plasmodium falciparum RH5 protein binds erythrocytes and elicits potent strain-transcending parasite-neutralizing antibodies. Infection and Immunity 82:152-164. doi: 10.1128/IAI. 00970-13, PMID: 24126527

Saito M, Sugano K, Nagai Y. 1979. Action of Arthrobacter ureafaciens sialidase on sialoglycolipid substrates. mode of action and highly specific recognition of the oligosaccharide moiety of ganglioside GM1. The Journal of Biological Chemistry 254:7845-654. PMID: 468792

Tham WH, Lim NT, Weiss GE, Lopaticki S, Ansell BR, Bird M, Lucet I, Dorin-Semblat D, Doerig C, Gilson PR, Crabb BS, Cowman AF. 2015. Plasmodium falciparum adhesins play an essential role in signalling and activation of invasion into human erythrocytes. PLOS Pathogens 11:e1005343. doi: 10.1371/journal.ppat. 1005343, PMID: 26694741

Tham WH, Wilson DW, Lopaticki S, Schmidt CQ, Tetteh-Quarcoo PB, Barlow PN, Richard D, Corbin JE, Beeson JG, Cowman AF. 2010. Complement receptor 1 is the host erythrocyte receptor for plasmodium falciparum PfRh4 invasion ligand. PNAS 107:17327-17332. doi: 10.1073/pnas.1008151107, PMID: 20855594

Triglia T, Thompson J, Caruana SR, Delorenzi M, Speed T, Cowman AF. 2001. Identification of proteins from plasmodium falciparum that are homologous to reticulocyte binding proteins in Plasmodium vivax. Infection and Immunity 69:1084-1092. doi: 10.1128/IAI.69.2.1084-1092.2001, PMID: 11160005

Varghese JN, Laver WG, Colman PM. 1983. Structure of the influenza virus glycoprotein antigen neuraminidase at 2.9 A resolution. Nature 303:35-40. doi: 10.1038/303035a0, PMID: 6843658

Volz JC, Yap A, Sisquella X, Thompson JK, Lim NT, Whitehead LW, Chen L, Lampe M, Tham WH, Wilson D, Nebl T, Marapana D, Triglia T, Wong W, Rogers KL, Cowman AF. 2016. Essential role of the PfRh5/PfRipr/CyRPA complex during Plasmodium falciparum Invasion of Erythrocytes. Cell Host \& Microbe 20:60-71. doi: 10.1016/j. chom.2016.06.004, PMID: 27374406

Weiss GE, Gilson PR, Taechalertpaisarn T, Tham WH, de Jong NW, Harvey KL, Fowkes FJ, Barlow PN, Rayner JC, Wright GJ, Cowman AF, Crabb BS. 2015. Revealing the sequence and resulting cellular morphology of receptor-ligand interactions during plasmodium falciparum invasion of erythrocytes. PLOS Pathogens 11: e1004670. doi: 10.1371/journal.ppat.1004670, PMID: 25723550

WHO. 2015. The world malaria report. 978:156515-156518 http://wwwwhoint/malaria/publications/worldmalaria-report-2015/report/en/.

Williams AR, Douglas AD, Miura K, Illingworth JJ, Choudhary P, Murungi LM, Furze JM, Diouf A, Miotto O, Crosnier C, Wright GJ, Kwiatkowski DP, Fairhurst RM, Long CA, Draper SJ. 2012. Enhancing blockade of plasmodium falciparum erythrocyte invasion: assessing combinations of antibodies against PfRH5 and other merozoite antigens. PLoS Pathogens 8:e1002991. doi: 10.1371/journal.ppat.1002991, PMID: 23144611

Wright KE, Hjerrild KA, Bartlett J, Douglas AD, Jin J, Brown RE, Illingworth JJ, Ashfield R, Clemmensen SB, de Jongh WA, Draper SJ, Higgins MK. 2014. Structure of malaria invasion protein RH5 with erythrocyte basigin and blocking antibodies. Nature 515:427-430. doi: 10.1038/nature13715, PMID: 25132548

Xu Y, Kershaw NJ, Luo CS, Soo P, Pocock MJ, Czabotar PE, Hilton DJ, Nicola NA, Garrett TP, Zhang JG. 2010. Crystal structure of the entire ectodomain of gp130: insights into the molecular assembly of the tall cytokine receptor complexes. Journal of Biological Chemistry 285:21214-21218. doi: 10.1074/jbc.C110.129502, PMID: 20489211 


\section{University Library}

\section{- M M N E R VA A gateway to Melbourne's research publications}

Minerva Access is the Institutional Repository of The University of Melbourne

\section{Author/s:}

Chen, L;Xu, Y;Wong, W;Thompson, JK;Healer, J;Goddard-Borger, ED;Lawrence, $\mathrm{MC}$;Cowman, AF

Title:

Structural basis for inhibition of erythrocyte invasion by antibodies to Plasmodium falciparum protein CyRPA

Date:

2017-02-14

Citation:

Chen, L., Xu, Y., Wong, W., Thompson, J. K., Healer, J., Goddard-Borger, E. D., Lawrence, M. C. \& Cowman, A. F. (2017). Structural basis for inhibition of erythrocyte invasion by antibodies to Plasmodium falciparum protein CyRPA. ELIFE, 6, https://doi.org/10.7554/ eLife.21347.001.

Persistent Link:

http://hdl.handle.net/11343/258098

License:

CC BY 